\title{
Adolescents in situations of poverty: resilience and vulnerabilities to sexually transmitted infections
}

\author{
Adolescentes em situação de pobreza: resiliência e vulnerabilidades às infecções sexualmente transmissíveis \\ Adolescentes en situación de pobreza: resistencia y vulnerabilidad a las infecciones de transmisión sexual
}

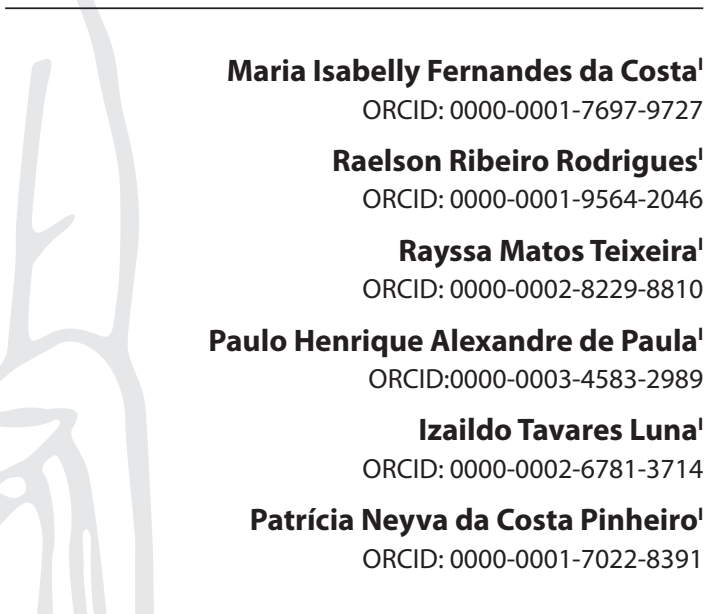

Universidade Federal do Ceará. Fortaleza, Ceará, Brazil.

How to cite this article:

Costa MIF, Rodrigues RR, Teixeira RM, Paula PHA, Luna IT, Pinheiro PNC. Adolescents in situations of poverty: resilience and vulnerabilities to sexually transmitted infections. Rev Bras Enferm. 2020;73(Suppl 4):e20190242. doi: http://dx.doi.org/10.1590/0034-7167-2019-0242

Corresponding author:

Maria Isabelly Fernandes da Costa E-mail: isabellyfernandes165@yahoo.com.br

EDITOR IN CHIEF: Dulce Barbosa ASSOCIATE EDITOR: Ana Fátima Fernandes

Submission: 06-23-2019

Approval: 03-23-2020

\begin{abstract}
Objective: To analyze the association between vulnerabilities to Sexually Transmitted Infections (STIS/HIV/AIDS) of adolescents in poverty and their level of resilience. Method: Cross-sectional study with 287 students between 11 and 17 years old in a school in the outskirts of Fortaleza-Ce. The study was conducted from August to October 2016. Three instruments related to characterization, vulnerability to STIs/HIV/AIDS and resilience were used. The association between the instruments was calculated using the Mann-Whitney and Kruskal-Wallis tests. Association between vulnerability to STIs/HIV/AIDS and resilience was assessed through the Spearman's correlation coefficient. Statistical significance was set at $p<0.05$. Results: There was a significant association between the factors "housing" $(p=0.022)$, "family income" $(p=0.037)$ and vulnerability to STIs/HIV/AIDS. Adolescents whose father has completed high school $(p=0.043)$ have moderately high resilience. Conclusion: Adolescents with low socioeconomic status and who live on less than a minimum wage tends to be more susceptible to vulnerabilities to STIS/HIV/AIDS and to have low resilience. Descriptors: Adolescent; Poverty; Sexuality; Vulnerable Populations; Nursing Services.
\end{abstract}

\section{RESUMO}

Objetivo: Analisar a relação entre as vulnerabilidades às Infecções Sexualmente Transmissíveis (IST/HIV/aids) de adolescentes em situação de pobreza e seu nível de resiliência. Método: Estudo transversal, com 287 escolares de 11 a 17 anos, na periferia de Fortaleza-Ce, entre agosto/outubro de 2016. Utilizaram-se três instrumentos relacionados a caracterização, vulnerabilidade às IST/HIV/aids e resiliência. A associação entre os instrumentos foi realizada através dos testes de Mann-Whitney e de KrusKal-Wallis, e a vulnerabilidade às IST/HIV/aids e a Resiliência através do coeficiente de correlação de Spearman, considerado estatisticamente significante $p<0,05$. Resultados: Houve associação significativa relacionada a "moradia" $(p=0,022)$, "renda familiar" ( $p=0,037)$ e vulnerabilidade às IST/HIV/aids. Os adolescentes cujo pai possui ensino médio completo $(p=0,043)$ possuem uma resiliência moderadamente alta. Conclusão: Adolescentes com baixos níveis socioeconômicos, que vivem com menos de um salário mínimo, tendem a ser mais suscetíveis às vulnerabilidades às IST/HIV/aids e a ter baixa resiliência.

Descritores: Adolescente; Pobreza; Sexualidade; Populações Vulneráveis; Serviços de Enfermagem.

\section{RESUMEN}

Objetivo: Analizar la relación entre la vulnerabilidad a las infecciones de transmisión sexual (ITS/VIH/SIDA) de los adolescentes en situación de pobreza y su nivel de resistencia. Método: Se trata de un estudio transversal realizado entre 287 escolares de 11 a 17 años en el suburbio de Fortaleza, Ceará entre agosto y octubre de 2016. Se utilizaron tres instrumentos relacionados con la caracterización, vulnerabilidad y resistencia a ITS/VIH/SIDA. La asociación entre los instrumentos se realizó con las pruebas de Mann-Whitney y de KrusKal-Wallis y la vulnerabilidad a ITS/VIH/SIDA y la Resistencia a través del coeficiente de correlación de Spearman, considerándose estadísticamente significativo $p<0,05$. Resultados: Hubo una asociación significativa relacionada con la "vivienda" ( $p=0,022)$, el "ingreso familiar" ( $p=0,037)$ y la vulnerabilidad a las ITS $/ \mathrm{VIH} / \mathrm{SIDA}$. Los adolescentes cuyo padre terminó la escuela secundaria $(p=0,043)$ tienen una resistencia moderadamente alta. Conclusión: Los adolescentes de nivel socioeconómico bajo, que viven con menos de un sueldo mínimo, tienden a ser más susceptibles a las vulnerabilidades de las ITS/VIH/SIDA y su resistencia es baja.

Descriptores: Adolescente; Pobreza; Sexualidad; Poblaciones Vulnerables; Servicios de Enfermería 


\section{INTRODUCTION}

Poverty is a cross-sectional phenomenon that involves several factors. It is considered a multidimensional problem that goes beyond economic issues. In the context of adolescence, the lack of supplies necessary for their development can make these individuals more vulnerable ${ }^{(1-2)}$.

Worldwide, the number of people living in extreme poverty has dropped from 1.9 billion to 836 million. In Brazil, $40 \%$ of Brazilians up to 14 years of age live in poverty, in a situation of vulnerability and are susceptible to Sexually Transmitted Infections (STIs) ${ }^{(3-4)}$.

It is estimated that, every day, there are more than 1 million new cases of STIs worldwide. Each year, there are around 357 million new infections with STIs, among which are chlamydia, gonorrhea, syphilis and trichomoniasis. This greatly increases the risk of acquiring or transmitting the Human Immunodeficiency Virus (HIV) ${ }^{(5)}$.

In recent years, the rates of STIs/HIV/aids have increased, especially among adolescents, as they are in a phase of biopsychosocial transformations, lack of knowledge about sexuality and restricted access to health services ${ }^{(6)}$.

In Brazil, the average age of onset of sexual activity is 14 to 15 years. At this age, $27.5 \%$ of adolescents who have had sexual intercourse are male, and only $61.2 \%$ used condoms in the first sexual intercourse. The early initiation of sexual activity, having multiple partners and not using condoms are risk factors for STIs/HIV/aids ${ }^{(7)}$.

In adolescence, vulnerability is associated with the rupture of bonds with parents, the discovery of new things, the biopsychosocial changes experienced and the context in which the adolescent is inserted. The interaction of adolescents with their surroundings can lead to risk events and affect the way they deal with stressful situations, making the individual more or less vulnerable ${ }^{(8)}$. Therefore, it is important to develop mechanisms that can help adolescents to overcome difficulties and adversities ${ }^{(9)}$.

Understanding the changes resulting from distressing experiences can be an element of protection and an important factor in the development and understanding of resilience and strength in situations of vulnerability. Resilience is defined as a positive response in conflictual situations and adversities ${ }^{(10)}$.

In this perspective, resilience is understood as the ability to face negative experiences and manifest a positive response, despite of the adverse event ${ }^{(11)}$. It is also related to social, psychological and environmental processes, and it is discussed, both at the theoretical and methodological levels, as a phenomenon that is intrinsic to the development of any human being ${ }^{(12)}$.

Furthermore, by understanding the vulnerability to STIs/HIV/ aids in adolescence, as well as the importance of developing mechanisms that can help adolescents in stressful/adverse events, the results of this study may support health promotion actions for adolescents and help them to develop resilience.

\section{OBJECTIVE}

To analyze the association between vulnerability to STIs/HIV/ aids among adolescents in situations of poverty and their level of resilience.

\section{METHOD}

\section{Ethical Aspects}

The research followed the ethical precepts established in Resolution 466/12 of the National Health Council and was approved by the Research Ethics Committee of the Federal University of Ceará.

\section{Study design, setting and period}

This is a cross-sectional study, carried out from August to October 2016, analyzing the association between vulnerability to STIs/HIV/aids among adolescents in situations of poverty and their level of resilience. The participants were from a public school located in outskirts of Fortaleza, the capital of a state in the Northeast Region of Brazil. According to the Human Development Index, this is an extremely poor area, with an average income of $\mathrm{R} \$ 349.75$, occupying the 15 th position in the ranking of extremely poor populations ${ }^{(13)}$.

\section{Population or sample; inclusion and exclusion criteria}

The study population consisted of 546 adolescents, with an intentional sample of 287 students, following the eligibility criteria: being in the 11-17-year age group, having up to 11 years of education, and living in a situation of poverty. A situation of poverty was defined by enrollment in the "Bolsa Família", a government program for low-income people ${ }^{(14)}$. Adolescents with cognitive problems that prevented them from answering the instruments were excluded.

\section{Study Protocol}

Data was collected using three self-administered instruments, with a mean duration of 45 minutes. Instruments were applied in a private room, in the morning and afternoon shifts, ensuring the privacy of the adolescent. The first instrument is a socio-demographic questionnaire that addresses biological and social aspects, such as age, gender, color/ethnicity, education, religion, civil status, number of people in the household, level of education and occupation of parents, housing and family income.

The second instrument is a questionnaire that is part of the Health and Prevention in Schools Program of the Brazilian Ministry of Health ${ }^{(15)}$. The instrument has the objective of assessing the vulnerability to STIs/HIV/aids and is composed of 11 multiple choice questions with answers divided into colors. The instrument was adapted by assigning scores to the colors, grading them from 0 to 2 points, where 0 was assigned to green answers, 1 to yellow answers and 2 to blue answers. The total score may vary from 0 to 22 points.

The cut-off score was 4 points; participants who scored less than 4 (score $<4$ ) were considered less vulnerable, while those whose total score was higher than 4 (score $>4$ ) were classified as more vulnerable ${ }^{(15)}$.

The third instrument was the Resilience $S c a l e^{(16)}$, translated and adapted $^{(17)}$ to Brazil. This is a 25 -item Likert scale ranging from 1 (strongly disagree) to 7 (strongly agree). Items are grouped in 
three factors: Factor I- Resolution of actions and values; Factor II- Independence and determination; and Factor III- Self-confidence and adaptability. The scale assesses the level of positive psychosocial adaptation to important life events and the degree of individual resilience (personal competence, acceptance of self and acceptance of life). It has a significant intra-observer reliability, with $95 \% \mathrm{Cl}$, interclass correlation of 0.746 and $\mathrm{Cl}$ of $0.624 \%$ and $0.829 \%$, showing a direct and significant correlation with self-esteem, family supervision, life satisfaction and social support, and it has a Cronbach's Alpha of 0.85 .

In this analysis, a cut-off point of 124 was adopted; scores> 145 indicate moderately high resilience, scores between 125 and 145 indicate moderately low to moderate resilience and scores $\leq 124$ indicate low resilience ${ }^{(17)}$.

As for resilience and adaptability, adolescents were divided into three groups $(A, B, C)$ : group $A$ comprises adolescents with scores $>145$ points, indicating moderately high resilience; group B comprises adolescents with moderately low to moderate resilience, with scores between 125 and 145; and group C comprises adolescents with a score $\leq 124$ points, indicating low resilience.

\section{Analysis of results and statistics}

The data were analyzed in the software IBM SPSS version 23. Absolute and relative frequencies were calculated for qualitative variables; mean and standard deviation were calculated for quantitative variables. The Mann-Whitney and Kruskal-Wallis tests were used to assess the association between biological and social factors and between vulnerability to STIs/HIV/aids and resilience. The association between vulnerability to STIs/HIV/ aids and resilience was evaluated using Spearman's correlation coefficient. Statistical significance was set at $p<0.05$.

\section{RESULTS}

The sample was composed of 287 adolescents, of which 191 (66.6\%) were male, 163 (58.8\%) were between 15 and 17 years old, 80 (27.9\%) were white, 178 (38\%) had more than 12 years of education, 271 (94.4\%) practiced a religion, 175 (61\%) were single, 159 (55.4\%) lived in a rented house and 234 (81.6\%) lived with two to five people. As for the level of education of parents, 29 fathers (10.1\%) and 31 mothers (10.8\%) had completed high school. Regarding occupation, 94 (32.8\%) fathers worked in the construction industry, and $119(41.5 \%)$ mothers worked at home; 87 (30.3\%) families lived with an income of less than two minimum wages.

Regarding their vulnerability to STIs, 212 (73.9\%) adolescents were considered more vulnerable, with a score $>4$. There was a statistically significant association in relation to housing $(p=0.022)$. It was observed that, among the adolescents who lived in and owned house, 103 (80.5\%) were considered more vulnerable to STIs/HIV/aids, while 109 (68.6\%) adolescents who lived in rented houses were less vulnerable (Table 1 ).

Family income also showed a statistically significant association with vulnerability to STIs/HIV/aids $(p=0.037)$. Adolescents who lived with less than one minimum wage $(<1 \mathrm{MW})$ were more vulnerable when compared to the others (Table 1).
Table 1 - Association between the biological and social factors of adolescents in poverty in Bairro Grande Bom Jardim, Fortaleza, Ceará, Brazil, 2018

\begin{tabular}{|c|c|c|c|}
\hline Variables & $\begin{array}{c}\text { Less } \\
\text { vulnerable } \\
n(\%) \\
(\text { scores < 4) }\end{array}$ & $\begin{array}{c}\text { More } \\
\text { vulnerable } \\
\text { n (\%) } \\
\text { (scores >4) }\end{array}$ & $p$ value \\
\hline Gender & & & $0.244^{1}$ \\
\hline Female & $21(28.3)$ & $75(35.4)$ & \\
\hline Male & $54(72.0)$ & $137(64.6)$ & \\
\hline Age group & & & $0.250^{2}$ \\
\hline 11 to 14 & $27(21.8)$ & $97(78.2)$ & \\
\hline 15 to 16 & $46(29.1)$ & $112(70.9)$ & \\
\hline 17 to 18 & $2(40)$ & $3(60)$ & \\
\hline Education & & & $0.492^{1}$ \\
\hline$<11$ years of education & $26(23.9)$ & $83(76.1)$ & \\
\hline$>11$ years of education & $49(27.5)$ & $129(72.5)$ & \\
\hline Color/ethnicity & & & $0.081^{2}$ \\
\hline White/Brown & 46 & 153 & \\
\hline Black & $28(34.1)$ & $54(65.9)$ & \\
\hline Yellow/Indigenous & 1 & 5 & \\
\hline Religion & & & $0.968^{2}$ \\
\hline Catholic & $42(26.9)$ & $114(73.1)$ & \\
\hline Protestant/Evangelical & $28(25.9)$ & $80(74.1)$ & \\
\hline No religion/other & 5 & 18 & \\
\hline Civil Status & & & $0.481^{2}$ \\
\hline Single & $46(26.3)$ & $129(73.7)$ & \\
\hline Married & $1(50)$ & $1(50)$ & \\
\hline In a relationship & $28(26.7)$ & $77(73.3)$ & \\
\hline Other & 0 & $5(100)$ & \\
\hline Housing & & & $0.022^{2}$ \\
\hline Owned house & $25(19.5)$ & $103(80.5)$ & \\
\hline Rented house & $50(31.4)$ & $109(68.6)$ & \\
\hline Number of people in the household & & & $0.265^{1}$ \\
\hline 2 to 3 people & $31(30.1)$ & $72(69.9)$ & \\
\hline 4 to 5 people & 35 & 96 & \\
\hline 6 or more people & $8(16.7)$ & $40(83.3)$ & \\
\hline Father's level of education & & & $0.769^{2}$ \\
\hline No information/no education & $16(22.9)$ & 56 & \\
\hline Up to 9 years of education & $50(28.7)$ & $124(71.3)$ & \\
\hline 10 to 12 years of education & $8(24.2)$ & $25(75.8)$ & \\
\hline Higher education & $1(12.5)$ & $7(87.5)$ & \\
\hline Mother's level of education & & & $0.136^{2}$ \\
\hline No information/no education & 12 & 55 & \\
\hline Up to 9 years of education & $55(31.3)$ & $121(68.8)$ & \\
\hline 10 to 12 years of education & $6(16.2)$ & $31(83.8)$ & \\
\hline Higher education & $2(28.6)$ & $5(71.4)$ & \\
\hline Father's occupation & & & $0.095^{2}$ \\
\hline At home & $8(2.8)$ & $5(1.74)$ & \\
\hline Informal work & $122(42.5)$ & $69(24.4)$ & \\
\hline Formal work & $37(12.9)$ & $12(4.1)$ & \\
\hline Does not work & $9(3.1)$ & $25(8.7)$ & \\
\hline Mother's occupation & & & $0.349^{2}$ \\
\hline At home & 142 (49.47) & $10(3.84)$ & \\
\hline Informal work & 37 (12.89) & $35(12.19)$ & \\
\hline Formal work & $31(10.80)$ & $7(2.43)$ & \\
\hline Does not work & $10(3.84)$ & $15(5.2)$ & \\
\hline Income & & & $0.037^{2}$ \\
\hline$<1 \mathrm{MW}$ & $26(29.9)$ & $61(70.1)$ & \\
\hline $1-2 \mathrm{MW}$ & 37 (31.6) & $80(68.4)$ & \\
\hline $2-3 \mathrm{MW}$ & $3(23.1)$ & $10(76.9)$ & \\
\hline$>3 \mathrm{MW}$ & $1(20)$ & $4(80)$ & \\
\hline No information & $8(12.3)$ & (87.7) & \\
\hline
\end{tabular}

Notes: ${ }^{*}$ Minimum wage of $R \$ 880,00$, according to Decree no. 8.618, effective in 2016. ${ }^{1}$ MannWhitney; ${ }^{2}$ Kruskal-Wallis

The adolescents were assessed for resilience and 125 (43.55\%) presented low resilience, with a score $\leq 124$. This implies that these adolescents have low psychosocial adaptability (Table 2). 
Table 2 - Distribution by group according to the psychosocial adaptability/ resilience of adolescents in poverty in Bairro Grande Bom Jardim, Fortaleza, Ceará, Brazil, 2018

\begin{tabular}{lcc}
\hline Groups & $\mathbf{n}$ & $\%$ \\
\hline A (> 145 - moderately high resilience) & 42 & 14.63 \\
B (125 a 145 - moderately low to moderate resilience) & 120 & 41.81 \\
C ( $\leq 124$ - low resilience) & 125 & 43.55 \\
\hline
\end{tabular}

Table 3 - Association between the Resilience Scale and the characteristics of adolescents in poverty in Bairro Grande Bom Jardim, Fortaleza, Ceará, Brazil, 2018

\begin{tabular}{|c|c|c|}
\hline Variables & $\begin{array}{c}\text { Resilience } \\
\text { Mean } \pm \text { standard deviation }\end{array}$ & $\begin{array}{c}p \\
\text { value }\end{array}$ \\
\hline \multicolumn{3}{|l|}{ Gender } \\
\hline Male & $127.1 \pm 18.1$ & $0.973^{1}$ \\
\hline Female & $127.8 \pm 15.4$ & \\
\hline \multicolumn{3}{|l|}{ Age group } \\
\hline 11 to 14 & $126.3(13.3)$ & \\
\hline 15 to 16 & $127.1(17.2)$ & $0.343^{2}$ \\
\hline 17 to 18 & $135.6(11.8)$ & \\
\hline \multicolumn{3}{|l|}{ School grade } \\
\hline $6^{\text {th }}$ Year & $126.9 \pm 16.5$ & $0.740^{1}$ \\
\hline $7^{\text {th }}$ Year & $128.0 \pm 16.2$ & \\
\hline \multicolumn{3}{|l|}{ Color/Ethnicity } \\
\hline White/Brown & $129.1 \pm 14.9$ & \\
\hline Black & $127.4 \pm 14.0$ & $0.767^{2}$ \\
\hline Yellow/Indigenous & $130.8 \pm 16.3$ & \\
\hline \multicolumn{3}{|l|}{ Religion } \\
\hline Catholic & $128.3 \pm 15.0$ & \\
\hline Protestant/Evangelical & $126.8 \pm 17.9$ & $0.782^{2}$ \\
\hline No religion/other & $128.4 \pm 16.8$ & \\
\hline \multicolumn{3}{|l|}{ Civil status } \\
\hline Single & $127.5 \pm 15.3$ & \\
\hline Married & $131.5 \pm 23.3$ & $0.916^{2}$ \\
\hline In a relationship & $127.3 \pm 17.9$ & \\
\hline Another type of relationship & $133.2 \pm 17.9$ & \\
\hline \multicolumn{3}{|l|}{ Housing } \\
\hline Owned house & $126.5 \pm 16.5$ & $0.476^{1}$ \\
\hline Rented house & $128.4 \pm 16.1$ & \\
\hline \multicolumn{3}{|l|}{ Number of people in the household } \\
\hline Two to three people & $133.5 \pm 11.0$ & \\
\hline Four to five people & $125.8 \pm 18.5$ & $0.135^{2}$ \\
\hline More than six people & $126.1 \pm 12.1$ & \\
\hline \multicolumn{3}{|l|}{ Father's level of education } \\
\hline Up to 9 years of education & $131.2 \pm 17.5$ & \\
\hline 10 to 12 years of education & $141.3 \pm 18.4$ & $0.043^{2}$ \\
\hline Higher education & $136.1 \pm 15.1$ & \\
\hline No education/No information & $116.5 \pm 2.1$ & \\
\hline \multicolumn{3}{|l|}{ Mother's level of education } \\
\hline Up to 9 years of education & $130.1 \pm 15.8$ & \\
\hline 10 to 12 years of education & $124.8 \pm 23.3$ & $0.352^{2}$ \\
\hline Higher education & $138.3 \pm 11.6$ & \\
\hline No education/No information & $118.5 \pm 4.9$ & \\
\hline \multicolumn{3}{|l|}{ Father's occupation } \\
\hline Yes, only at home & $127.1 \pm 21.4$ & \\
\hline Yes, informal work & $127.5 \pm 16.1$ & 0.987 \\
\hline Yes, formal work & $127.6 \pm 18.0$ & \\
\hline Does not work & $128.7 \pm 14.7$ & \\
\hline \multicolumn{3}{|l|}{ Mother's occupation } \\
\hline Yes, only at home & $127.7 \pm 15.9$ & \\
\hline Yes, informal work & $130.6 \pm 14.7$ & 0.157 \\
\hline Yes, formal work & $129.1 \pm 17.4$ & \\
\hline Does not work & $119.9 \pm 16.1$ & \\
\hline \multicolumn{3}{|l|}{ Income } \\
\hline$<1 \mathrm{MW}$ & $126.6 \pm 13.8$ & \\
\hline $1-2 \mathrm{MW}$ & $129.1 \pm 18.4$ & \\
\hline $2-3 \mathrm{MW}$ & $132.2 \pm 17.8$ & $0.299^{2}$ \\
\hline$>3 \mathrm{MW}$ & $135.20 \pm 14.7$ & \\
\hline No information & $124.6 \pm 14.9$ & \\
\hline
\end{tabular}

There was a statistically significant association with the father's education ( $p=0.043$ ): adolescents whose father had completed high school $(141.3 ; \pm 18.4)$ were considered more resilient. There were no significant differences between the scale of resilience and social characteristics of the adolescents. However, female adolescents, between 15 and 17 years old, with more than 11 years of education, who self-identified as yellow, who did not practice a religion, who were in another type of association, who lived in a rented house, with two people and with an income $>3$ minimum wages were more resilient when compared to the others (Table 3).

The analysis of the association between vulnerability to STIs/ HIV/aids and resilience showed a statistically significant association, with $\mathrm{p}=0.022$, with an inversely proportional association, with $p=-0.135$, which means that high values in the vulnerability questionnaire were associated with low values on the resilience scale.

\section{DISCUSSION}

Poverty and social inequalities are vulnerabilities that enhance other vulnerabilities, especially in adolescence, when living conditions, housing, education and family relationships affect the development of mechanisms to deal with adverse situations, such as vulnerability to STIs/HIV/aids ${ }^{(18-19)}$.

Early initiation of sexual activity, having multiple partners, not using condoms, low level of education, low socioeconomic status and the search for pleasure and for the discovery of new things ${ }^{(20)}$ are situations that make adolescents susceptible to STIs/HIV/aids, especially male adolescents ${ }^{(21)}$. In this study, 212 (73.9\%) adolescents were considered vulnerable to STIs/HIV/aids, of which 137 (64.6\%) were male and between 15 and 16 years old.

The susceptibility of boys to STIs/HIV/aids is associated with exposure to risk factors are common at this phase, such as drug and alcohol use, smoking, illicit drugs, and involvement in night parties at an increasingly early age ${ }^{(22)}$. The surroundings and living conditions of the individual are other factors that can make them vulnerable to STIs/HIV/aids, as demonstrated in this study, which found that adolescents living in an owned house and with a family income $(p=0.037)$ of less than one minimum wage $(<1 \mathrm{MW})$ were more vulnerable.

Despite of living in an owned house, the adolescents in this study live in a place classified by the Human-Income Development Index as an extremely poor neighborhood, which makes them susceptible to STIs/HIV/aids ${ }^{(13)}$. A study conducted in Bahia, Brazil with 383 adolescents found a negative association between family income and vulnerability to STIs/HIV/aids, meaning that individuals with low socioeconomic status are more susceptible to infections and illness ${ }^{(23)}$.

In the North and Northeast Regions of Brazil, adolescents live with a per capita income of less than half of a minimum wage. In Ceará, 38\% of adolescents between 12 and 17 years old live in families with a per capita income of less than half a minimum wage, showing that 7.9 million of these adolescents are in situations of poverty ${ }^{(13-24-25)}$.

Experiencing a situation of poverty makes the individual more fragile, especially adolescents, who are in a phase of profound biological, psychological, social and emotional changes and increased risks to their health. In this phase, the development of mechanisms that increase their resilience is essential ${ }^{(26)}$. However, 
poverty, low socioeconomic status, family income and family relationships can a have a negative influence on the development of resilience ${ }^{(27)}$, as observed in this study, which found that 125 (43.55\%) of the adolescents in a situation of poverty have a low resilience, that is, low psychosocial adaptability.

Corroborating these data, a study carried out with 1,250 adolescents in school in del País Vasco, Spain, found that 638 (51\%) of the adolescents who lived with more than two people tended to experience conflicts of autonomy related to freedom and developed characteristics that made them less resilient when dealing with adversities, such as vulnerability to STIs/HIV/aids ${ }^{(28)}$.

Studies carried out with people with low socioeconomic status and/or in situation of poverty show a greater susceptibility to $\mathrm{STIs} / \mathrm{HIV} /$ aids and a low resilience ${ }^{(29)}$, especially among men who have sex with men (MSM) and people already infected with HIV(30).

In the South of Mexico, a study carried out with 182 male adolescents who were socially and economically unstable and who started sexual activity before the age of 15 showed that this group had a high risk for STIs/HIV/aids and a low resilience ${ }^{(31)}$. Therefore, it corroborates the results of this study, which found that adolescents with low socioeconomic status tend to be more susceptible to STIs/ HIV/aids and to experience more difficulty to develop resilience.

Influence of parents, family dialogue and the level of education of parents are factors with a strong influence on the children's resilience $^{(32)}$. In this study, the level of education of parents $(p=0.043)$ was a significant factor, which is similar to the data found in studies with adolescents in school. These studies show that parents can maximize the potential and the personal, interpersonal and social development of their children and support the process of adaptation to adversities and decision-making in situations experienced ${ }^{(33)}$.

Even though it did not present a significant association in this study, studies demonstrate that religion in associated with subjective processes that help individuals to give new meaning to situations of adversity and to create mechanisms that help them develop resilience ${ }^{(34-35)}$.

\section{Limitations of the study}

The limitations of this study are related to the long time to return the consent terms duly signed by parents and/or guardians, the difficulty to respond to the instruments, the loss of participants throughout data collection, the data collection carried out in just one school and the dangerousness of the area, which compromised the entry and exit times in the school.

\section{Contributions to the area of Nursing, Health or Public Health}

It is expected that the findings of the present study can contribute to the development of resilience among adolescents and to the reduction of the vulnerabilities to which they are exposed, through educational strategies developed by health professionals and schools, through the Health in School Program and public policies aimed at promoting adolescent health.

\section{CONCLUSION}

The results showed a statistically significant association between housing, family income and vulnerability to STIs/HIV/aids. This data indicates that adolescents living in an owned house with less than a minimum wage are more vulnerable and have low resilience, that is, low psychosocial adaptability. On the other hand, adolescents with moderately high resilience were those whose father had completed high school.

Although not statistically significant, female adolescents, between 15 and 17 years old, with more than 11 years of education, who self-identified as yellow, who did not practice a religion, who were in another type of relationship, who lived in a rented house, with two people and with a family income $>3$ minimum wages were considered more resilient in this study.

As for vulnerability to STIs/HIV/aids and resilience, it was statistically inferred that high values in the vulnerability questionnaire were associated with low values on the resilience scale. Finally, the results illustrate the importance of actions that promote the development of resilience mechanisms, which should be carried out in all settings and contexts in which adolescents are inserted.

\section{FUNDING}

National Council for the Improvement of Higher Education - CAPES.

\section{REFERENCES}

1. Valverde MC. A interdependência entre vulnerabilidade climática e socioeconômica na região do ABC Paulista. Ambient Soc. 2017; 20(3):3960. doi: 10.1590/1809-4422asoc66r2v2032017

2. Matos LA, Cruz EJS, Santos TM, Silva SSC. Resiliência Familiar: o olhar de professores sobre famílias pobres. Psicol Esc Educ. 2018;22(3):493501. doi: 10.1590/2175-35392018038602

3. Programa das Nações Unidas para o Desenvolvimento. Índice do Relatório do Desenvolvimento Humano. O trabalho como motor do desenvolvimento humano [Internet]. 2018 [cited 2018 Dec 06]. Available from: http://hdr.undp.org/sites/default/files/2018_human_ development_statistical_update.pdf

4. Instituto Brasileiro de Geografia e Estatística. Censo demográfico de 2010[Internet]. 2010[cited 2018 Dec 06]. Available from: https:// biblioteca.ibge.gov.br/visualizacao/periodicos/93/cd_2010_caracteristicas_populacao_domicilios.pdf

5. Ministério da Saúde (BR). Secretaria de Vigilância em Saúde. Departamento de DST, Aids e Hepatites Virais. Bol Epidemiol Sífilis [Internet]. 2017[cited 2018 Dec 06]. Brasília: Ministério da Saúde; 2017[cited 2018 Dec 06]. Available from: http://portalarquivos.saude.gov.br/images/ pdf/2017/novembro/13/BE-2017-038-Boletim-Sifilis-11-2017-publicacao-.pdf 
6. Fundo de População das Nações Unidas. Fecundidade e maternidade adolescente no cone sul: anotações para a construção de uma Agenda Comum 2016 [Internet]. Chile: Escritório Regional da América Latina e Caribe; 2016[cited 2018 Dec 06]. Available from: http://www. unfpa.org.br/Arquivos/fecundidade_maternidade_adolescente_conesul.pdf

7. Silva ATM, Sousa GD, Lohmann CM, Filho ESF, Pinheiro WS, Júnior JMS et al. Vulnerability in adolescence: a case report of attempted abortion and sexual violence. J Hum Growth Develop. 2017;27(1):117-23. doi: 10.7322/jhgd.127686

8. Jorge KO, Ferreira RC, Ferreira EF, Kawachi I, ZPM, Pordeus IA. Influência do grupo de pares e uso de drogas ilícitas entre adolescentes brasileiros: um estudo transversal. Cad Saúde Pública. 2018; 34(3):e00144316. doi: 10.1590/0102-311x00144316

9. Oliveira KS, Nakano TC. Avaliação da resiliência em Psicologia: revisão do cenário científico brasileiro. Psicol Pesq. 2018;12(1):73-83. doi: $10.24879 / 2018001200100283$

10. Nascimento MS, Lippi UG, Santos AS. Social and individual vulnerability and teenage pregnancy. Rev Enferm Aten Saúde. 2018;7(1):15-29. doi: 10.18554/reas.v7i1.3114

11. Arrogante O. Resiliencia en enfermería: definición evidencia empírica e intervenciones. Index Enferm. 2015;24(4):232-35. doi: 10.4321/ S1132-12962015000300009

12. Guilera G, Pereda N, Paños A, Abad J. Assessing resilience in adolescence: the Spanish adaptation of the Adolescent Resilience Questionnaire. Health Qual Life Outc. 2015;13:100. doi: 10.1186/s12955-015-0259-8

13. Instituto de Pesquisa Econômica Aplicada. Atlas da Violência 2018 [Internet]. Brasília, 2018[cited 2018 Dec 06]. Available from: http://www. ipea.gov.br/portal/images/stories/PDFs/relatorio_institucional/180604_atlas_da_violencia_2018.pdf

14. Silva AMVL, Taquette SR, Hasselmann, MH. Family violence and body mass index among adolescents enrolled in the Bolsa Família Program and treated at a primary care clinic. Cad Saúde Pública. 2014;30(3):645-56. doi: 10.1590/0102-311X00175812

15. Ministério da Saúde (BR) Programa Nacional de DST e Aids. Eu preciso fazer o teste de HIV/Aids. Mobilização Nacional de Adolescentes e Jovens do Ensino Médio para prevenção do HIV/Aids. Ministério da Saúde [Internet]. 2013 [cited 2018 Dec 06]. Available from: https://www. unicef.org/brazil/pt/precisofazeroteste.pdf.

16. Wagnild GM, Young HM. Development and psychometric evaluation of the Resilience Scale. J Nurs Measur [Internet]. 1993 [cited 2018 Dec 06];1(2):165-78.

17. Pesce RP, Assis SG, Avanci JQ, Santos NC, Malaquias JV, Carvalhaes. Adaptação transcultural, confiabilidade e validade da escala de resiliência. Cad Saúde Pública. 2005;21(2):436-48. doi: 10.1590/S0102-311X2005000200010

18. Silva C; Martinez-Guzmán, ML. El self adolescente desde la perspectiva contextual: pobreza, viviendas sociales, apoyo parental y participación. Rev Latino-Am Cienc Soc Niñez Juven. 2017;15(1):117-30. doi: 10.11600/1692715x.1510605022016

19. Costa MIF, Luna IT, Pinheiro PNC, Rodrigues RR, Vieira NFC, Gubert FA, et al. Social determinants of health: risks and vulnerability in adolescence. Intern Arch Med. 2016;9(1):1-9. doi: 10.3823/2037

20. Barros CRS, Zucchi EM, Schraiber LB, França Junior I. Individual- and contextual-level factors associated with client-initiated HIV testing. Rev Bras Epidemiol. 2017;20(3):394-407. doi: 10.1590/1980-5497201700030004

21. Aragão JS, França ISX, Coura AS, Medeiros CCM, Enders BC. Vulnerability associated with sexually transmitted infections in physically disabled people. Ciênc Saúde Coletiva. 2016; 21(10):3143-52. doi: 10.1590/1413-812320152110.20062016

22. Castro JLC, Santos JVO, Araújo LF, Faro A, Rocha APP, Reis ST. Representações sociais do VIH/SIDA para adolescentes: uma abordagem estrutural. Anál Psicol. 2019;37(1):15-27. doi: 0.14417/ap.1492

23. Brignol S, Dourado I, Amorim LD, Kerr LRFS. Vulnerability in the context of HIV and syphilis infection in a population of men who have sex with men (MSM) in Salvador, Bahia State, Brazil. Cad Saúde Pública. 2015;31(5):1035-48. doi: 10.1590/0102-311X00178313

24. Instituto de Pesquisa Econômica Aplicada. ODS - Metas Nacionais dos Objetivos de Desenvolvimento Sustentável. Brasília, 2018.

25. Ministério da Saúde (BR). Boletim Epidemiológico HIV/aids [Internet]. Secretaria de Vigilância em Saúde. Brasília: Ministério da Saúde, 2019[cited 2018 Dec 06]. Available from: http://www.aids.gov.br/pt-br/pub/2019/boletim-epidemiologico-de-hivaids-2019

26. Araújo LF, Leal BS, Santos JVO, Sampaio AVC. Análise da resiliência entre pessoas que vivem com HIV/AIDS: um estudo psicossocial. Psic: Teor Pesq. 2019;35e35416. doi: 10.1590/0102.3772e35416

27. Luzivalda GD, Robério DF. Relação entre locus de controle e resiliência: um estudo com profissionais contábeis. UFSC. 2016;13(29):69-90. doi: 10.5007/2175-8069.2016v13n29p69

28. Fernandes de Araújo LB, María P. Resiliencia en adultos: una revisión teórica. Ter Psicol. 2015;33(3):257-76. doi: 10.4067/ S0718-48082015000300009

29. Freitas FRS, Santos JVDO, Araújo LF. Representaciones sociales de agentes comunitarios de salud sobre el SIDA. Perspectivas en Psicología. 2019 [cited 2019 Dec 18];16(1):76-87. Available from: http://www.seadpsi.com.ar/revistas/index.php/pep/article/view/408/pdf

30. Castillo-Arcos LC, Álvarez-Aquirre A, Bañuelos-Barrera Y, Valle-Solís MO, Valdez-Montero C, Kantún-Marín MAJ. Edad, Género y Resiliencia en la Conducta Sexual de Riesgo para ITS en Adolescentes al Sur de México. Enferm Glob. 2017;16(45):168-87. doi: 10.6018/eglobal.16.1.234921

31. Dray J, Bowman J, Campbell FM, Freund M, Hodder R, Wolfenden L, et al. Effectiveness of a pragmatic school-based universal intervention targeting student resilience protective factors in reducing mental health problems in adolescents. J Adolesc. 2017;57:74-89. doi: 10.1016/j. adolescence.2017.03.009 
32. Duenas Herrera, X, Mateus SG, Rodríguez JLD, Vera DCL. A resiliência no logro educacional dos estudantes colombianos. Rev Colomb Educ. 2019;76:69-90. doi: 10.17227/rce.num76-8037

33. Ahn GM, Dell'aglio DD. A religiosidade em adolescentes brasileiros. Rev Psicol IMED. 2017;9(1):38-54. doi: 10.18256/2175-5027.2017. v9i1.1541

34. Peltz L, Moraes MG, Carlotto MS. Resiliência em estudantes do ensino médio. Psicol Esc Educ. 2016;14(1):87-94. doi: 10.1590/ S1413-85572010000100010

35. Mata SSR, Martínez AM, Ortega FZ, Cuberos RC, Molero PP, Valero GG. Capacidad de resiliencia según tendencia religiosa y género en universitarios. Rev Electron Investig Educ. 2019;21(1):1-11. doi: 10.24320/redie.2019.21.e15.2016 